\title{
The Protagonist and the City: Istanbul in Orphan Pamuk's $A$ Strangeness in My Mind and The Museum of Innocence
}

\author{
Abdulrahman Mokbel Mahyoub Hezam \\ Department of English, Faculty of Arts \\ Taiz University, Yemen \\ $\&$ \\ Department of Languages and Translation \\ Faculty of Science and Arts \\ Taibah University, Al-Ola, Saudi Arabia
}

\begin{abstract}
The study is an attempt to focus on one of the world's biggest cultural cities; Istanbul through the works of one of Turley's great modernist writers Orphan Pamuk. The study tries to answer the following question: How does Pamuk use the personal stories of his characters to chronicle the historical development of Istanbul? Two novels have been selected for the study; A Strangeness in My Mind and The Museum of Innocence. The significance of the study lies in trying to show how these two texts, not only reveal the writer's reflections on urban space, but also show the character's experience in urban space and how the author uses these experiences to chronicle the history of the city. The study shows that the role of Istanbul in Pamuk's novels moves from the setting for the action to an active element of the action and relation between the characters in these novels and Istanbul is a relation that evolves with time, wherein, both the variables are influenced by the action of one another.

Keywords: Istanbul, Pamuk, Turkish novel, urban literature

Cite as: Hezam, A. M. M. (2020). The Protagonist and the City: Istanbul in Orphan Pamuk's A Strangeness in My Mind and The Museum of Innocence. Arab World English Journal for Translation \& Literary Studies 4 (3) 87-96 . DOI: http://dx.doi.org/10.24093/awejtls/vol4no3.7
\end{abstract}




\section{Introduction}

The city as a setting of literature has been a central theme and a key motif in modernist literature and a recurrent concern of thematically oriented criticism. The novel is considered the literary form of the city as its appearance coincided with the emergence of big European cities. Many of the world's best novels are set in cities and many novelists have been considered the voices of their cities. One hears of Dickens' London, Joyce's Dublin, and Mahfouz's Cairo. Numerous novels and poems reflect the ways in which cities generate states of shock, exhilaration, alienation, anonymity, confusion or thrill (Mullin, 2016). Burton Pike in The Image of the City in Modern Literature, tells us that" The city always speaks, and with many voices. It has been a powerful image in literature since literature began (Pike, 1981). When we talk of the urban space, we do not mean only the physical and natural entities comprised of roads, houses, public facilitations, but also social space composed of government and other management institutions. Lefebvre (1991) defines urban space as "the place where people walk around, find themselves standing before and inside piles of objects, experience the intertwining threads of their activities until they become unrecognizable, entangle situations" (56). Williams (1973) sees urban space as

"The great buildings of civilization, the meeting places, the libraries, the theatres and domes; and often more moving than these, the houses, the streets, the press and excitement of so many people with so many purposes. I have stood in so many cities and felt this pulse: in the physical differences of Stockholm and Florence, Paris and Milan "(p. 6)

The city is even more than" the place where people walk around" and " The great buildings of civilization". It is also a psychological state that impacts the actions of the characters.

In contemporary literature, the modern city is shown to be very complex. There are a number of writers who move towards the physical reality of the modern urban life and surroundings. Cities are the settings of complex and varied global and local interconnections that have the capability to generate varied social, economic, political dimensions. Lehan (1998) explores the dynamism of urban imagery and the links between literary expression and the history of the city. He rightly argues that transformations in the structure and role of cities influenced the form of the urban novel, linking developments in urban literature with developments of the city, attributing various narrative methods and trends to historical stages of urbanization. Jones (2014) sees that cities are manifested with collective identity that carefully maneuver the personality of an individual or a collective group. Individuals are seemingly impacted by the prevailing sense of the psychology that the cities are inculcated with (Jones, 2014).

\section{Objectives of the Study}

The most important objective of this study is to make a modest contribution to the field of urban literature through focusing on one of the world's biggest cultural cities; Istanbul and its representation and role in the works of one of Turley's great modernist writers Pamuk. The study tries to answer the following questions:

- How was Pamuk connected to his city?

Arab World English Journal for Translation \& Literary Studies 
- How does he present it in his works?

- How does he use the personal stories of his characters to chronicle the historical development of Istanbul?

- How does the city affect the behavior of the protagonist in the two novels?

\section{Significance of the Study}

The significance of the study lies in the fact that these two texts not only reveal the writer's reflections on urban space, but also show the character's experience in urban space especially psychological experience. It is a modest contribution to the study of the relationship between novel and the city. The role of Istanbul in Pamuk's novels moves from the setting for the action to an active element of the action. Through examining relevant selected texts by Pamuk that deal with the Istanbul, the researcher tries to construct a literary image of the space of this city in 20th $\mathrm{c}$.

\section{Literature Review}

Literature is connected with cities even before the appearance of the novel as a literary form. This relationship between literature and the city developed through ages. Lehan (1998) examines the dynamism of urban imagery, exploring links be- tween literary expression and the history of the city. In a sweeping analysis of western literature, Lehan thinks that as the city grew and its social and economic functions became more complex, writers developed new ways with which to deal with the metropolitan landscape. Lehan thinks that various stages of urban development created new ways of conceptualizing the city. In his preface to Writing the City: Urban Visions and Literary Modernism, Harding (2003)states that the most important work of art created by the city is the city itself, because in its totality, urban civilization represents the peak of human achievement. He discusses culture cities that are symbols used by the authors to legitimize their struggle for cultural authority-Miles in Cities and Literature offers a critical introduction to the relation between cities from the late eighteenth to twenty-first centuries. He examines examples of writing from different parts of the world including Europe, North America and post-colonial countries. Judith Flanders wrote a book entitled The Victorian City: Everyday Life in Dickens' London. The main argument of the book is that Dickens and London need to be understood together, not simply because Dickens loved London and set novels in it but because Dickens and London were formative of one another. The book is of interest to social and urban historians and literary critics interested in sociocultural contexts.

Wesselman (2012) examines the literary representations of the postmodern city. He comments that while the early decades of the 20th century were characterized by the metropolis that have high concentration of people and enterprise, the second half of the 20th century is marked by a changed usage of existing urban space with a different kind of city - sprawling, flexible, to be understood in different frameworks. This study deals with aspects of the postmodern city by looking at American literary works from the 1960s to the end of the century. These facets are represented in literary works, of course, but the researcher's usage of these texts is clearly geared towards looking beyond literary categories. Literary works offer a reflection of and on the city. The researcher's aim is to approach urban topics by using literature as a way of thinking about the city, which can therefore be brought together with theoretical of social scientific ways of thinking.

Arab World English Journal for Translation \& Literary Studies 
Some studies focused on the representation of a city in the writing of an author. Vermeulen (2013) reveals that while Teju Cole's novel Open City probes rather than confirms an aesthetic cosmopolitan program using a flat, nearly callous tone, it shows the incompetence of contemporary calls for aesthetic and memorial cosmopolitan practices to deal with a global landscape full of injustice and inequality. Vermeulen goes on to say that Open City's successful blend of metropolitanism, aestheticism, and intercultural curiosity sharply connects it to a cosmopolitan tradition. He concludes that from its title onward, Open City seems to assimilate the cosmopolitan principle that the cultivation of curiosity and attentiveness is the appropriate tool for fostering connections beyond cultural, ethnic, or national borders. Neumann and Kappel (2019) explore outlines of literary musicality in the novel, showing the relationship between literature and music and how they are linked to the novel's main themes. The researchers show how intermedial references in Open City create an additional meaning. The researchers argue that the contrapuntal structure of the novel clashes with the protagonist-narrator's contrapuntal reading of urban places and histories, asking readers to rethink conventionalized notions of black diasporic subjects.

There are major cities that feature in literature such as London, Paris, New York, Cairo, etc. Another major city which features in literary works is Mumbai. Dusunge believes that cities must be understood from various perspectives that adhere to the social, cultural, economic and political constructs. This understanding will aid in the solving the pressing issues that plague the development of the current city or state. Rameshwar mentions that the idea of a city or a state is not just limited to its geographical boundaries, rather, it is defined by the collective approach of the population which reflects the psychological state of the city. Cities are defined not only by their buildings, roads, infrastructure and various materialistic aspects, but also by the intricacies that occur within their geographical realm.

Ledden (1998) focuses on the educational system and status of social classes in Dublin, Ireland. He explores the Irish educational system and social class as represented in the writings of James Joyce. He examines several aspects including the practice of religion, the role of newspapers, middle class education and class distinctions in educational system. Sometimes researchers carry out comparative studies on the way two writers represent their respective cities in their works. Jay Clayton gives a comparative study of Dickens's London and Joyce's Dublin. $\mathrm{He}$ argues that with the possible exception of Flaubert, the works of Charles Dickens represent a more significant intertext for James Joyce than those of any other 19th-century novelist. He shows that examining the relationship between the two writers highlights the intertwined destinies of London and Dublin (Ledden ,1998)

Studying the city in literature is not limited to the western literature. There are several studies that deal with the representation of the city in literature in Third World countries. Sryfi (2018) argues that a study of how city space is portrayed in the Moroccan novel in Arabic is a useful contribution to the overall study of the importance of space in fiction. This dissertation rereads, examines, and analyzes the use of the city landscape in four Moroccan novels in Arabic. It critically re-evaluates both space and spatiality as used by two Moroccan authors; Muhammad

Arab World English Journal for Translation \& Literary Studies 
Shukri and Muhammad Zafzaf. The focus is on four novels by these two authors, works that provide representative depictions of the two cities-Tangier and Casablanca. The study highlights the Moroccan city and traces its evolving role from a mere background to an actively productive element (Mbarek Sryfi ,2018).

\section{Methodology}

The research is theoretical and analytical in nature and based on library materials. The procedure of data analysis is based on close reading and text analysis. Previous studies are presented before focusing on Istanbul in the novels of Pamuk. Two novels have been selected for the study; A Strangeness in My Mind and The Museum of Innocence. The image of Istanbul in the writers' novels is analyzed.

\section{Orphan's Istanbul}

The Nobel presentation speech addresses Pamuk as the writer who metamorphosed Istanbul into an indispensable literary territory comparing Pamuk's Istanbul to Dostoyevsky's St. Petersburg, Joyce's Dublin or Proust's Paris. Istanbul as seen in the works of Pamuk is "a place where readers from all corners of the world can live another life, just as credible as their own, filled by an alien feeling that they immediately recognize as their own" (Award speech, 2006). Like, London and Paris, the major western cultural centers, Istanbul is one of the most important cultural centers in the Orient. Istanbul is an emblem of civilization and culture as one finds in its history, the maximum concentration for the power and culture of Turkish community. It is the place where the diffused rays of many beams of life fall into focus, with gains in social effectiveness and significance. Istanbul is the city of two civilizations that at a certain age in history have formed a happy marriage. The first of these, the Islamic civilization hundreds of years old, the second, is the European civilization. Istanbul is the sine qua non of the global city because in every respect it encapsulates the processes of globalization. It represents the movability and cosmopolitanism of the global city, and the fluidity, and ambivalent sense of home that has come to characterize diasporic populations. The European foreign cultural practices coexist with the remnants of the former, collapsed civilization - the Ottoman Empire.

According to Afridi and Buyze, (2012) Pamuk "represents a mélange of voices in his complicated and multifaceted existential and political narratives of ordinary lives" (23). He has explored different literary forms ranging from realism to modernism to Sufi meta-fiction to postmodernism. With his combination of the postmodern style and mysticism, he has taken the standard of the Turkish novel to a different level. As a novelist, Pamuk is comfortable weaving the threads of modern Turkish life and politics through various settings. He writes novels that examine the paradoxes and interconnections of his country's culture and politics, revealing bare the contradictions of perspective that shadow the Turkish society. Orphan filled his books with the details of street names and neighborhoods; was interested in the physical environment of the citythe architecture, the noise, the air quality, the historical places. He knew that urban life encompassed all classes and occupations - lawyers, politicians, journalists, editors, scholars, beggars, day laborers, pub keepers, and teachers. The process of transformation from a traditional 
society to a modern industrial one in the twentieth century was traumatic on the part of Istanbul 's residents.

According to Levy (1978), the role of a city in a novel moves from being the setting for the action in the novel to be an active part of that action. The buildings in Istanbul symbolized ideas, such as, patriotism, religious identity and regal power. Pamuk's novels investigate the ongoing search for Turkish identity, portrayed and integrated as a clash of contradictions that needs to be conquered: East and West, Turkish majority and former imperial minorities, nationalism and cosmopolitanism, cultural homogenization and cultural pluralism. Much of the work of Pamuk is marked by an aspiration for a brilliant past as well as an outrage at the corruption that distorts that past. The contradiction, thus, exists in the writer's mind, in his novels and in his beloved city.

\section{A Strangeness in My Mind}

It is an urban novel narrating the life and love story of an Istanbul street seller named Mevlut Karataş. The main theme of the novel is the process of Istanbul's transformation from an old city into a booming metropolis. This is paralleled to the changes taking place in the protagonist's life who witnessed the socio-political, cultural, economic, and environmental changes Istanbul underwent during the period from 1969 to 2012. Like many Turkish people at that time, Mevlut came to Istanbul at the age of twelve to accompany his father who had already migrated to the metropolis from a Central Anatolian village. . Throughout A Strangeness in My Mind, Mevlut wanders in the streets of Istanbul every day trying to understand his strange feelings and thoughts regarding many things like life, change and love. The city in the novel is more than a setting. It is presented as a character in the novel or a force with which the protagonist is in love and conflict at the same time. Mevlut consistently doubts his belonging to the city whose streets he has learnt inch by inch. He is not sure whether he can be accepted by the city as a true inhabitant or discarded like trash. Mevlut's desire is developing a sense of belonging and becoming an inseparable part of the city and the novel is about his struggle to exist in the modernization process of the ancient metropolis

A Strangeness in My Mind follows Istanbul's urban transformation movements and explains the effects of this transformation on social memory and urban memory through the story of the protagonist. This transformation is sometimes painful to the character "On the Taksim side of the six-lane boulevard that was being opened, the destruction of large apartment buildings over sixty-seventy years has affected him the most" (Pamuk, 2014, p. 260). Old places are destroyed and replaced with new ones

"Many of the three-story houses in the gardens, which made up a large part of the city, were demolished, and high-rise apartments where the residents of the upper floors would not hear the voice of a street vendor was erected "(Pamuk, 2014 p. 28).

In twenty-five years, all of the first buildings, single-storey briquette structures were destroyed and these places became part of the city like Zeytinburnu, Gaziosmanpaşa, Ümraniye" (p. 366) This transformation is not limited to buildings. Even people were transformed. "While the old people 
disappeared from sight with their buildings, new people settled to higher, more intimidating, more concrete buildings" (pp. 457-458). Mevlüt felt that he was not one of these new people. He felt he was becoming more and more alienated to Istanbul as time passed. Maybe it is because of the millions of new people and their new homes, high buildings, shopping centers that have grown up like "unstoppable flood waves" (p. 457).

\section{Museum of Innocence}

Pamuk was collecting relics of the past for his project Museum of Innocence in the same time he was writing a novel and both works were aimed at testifying a historical period of the city of Istanbul especially between the 1960s and the 1980s. The Museum of Innocence built in Istanbul contains items apparently belonging to the narrator of the novel bearing the same title, which was published in 2008. In the book, the protagonist Kemal collects a big collection of objects linked to his sweetheart, and at the same time to the period of their love story, as a way to get over the destructive sadness deriving from her loss. Kemal's personal story is narrated to the reader through making constant reference to the objects that will be exhibited in the future museum.

Sometimes, thus, consoled, I would imagine it possible for me to frame my collection with a story, and I would dream happily of a museum where I could display my life - the life that first my mother, and then Osman, and finally everyone else thought I had wasted where I could tell my story through the things that Füsun had left behind, as a lesson to us all (Pamuk, 2008, p.307)

The objects do not only tell the personal story of one individual but also the story of the whole city and preserve the common memory of world that had disappeared just like the protagonist's beloved. The novel transform time into a literary work while the museum transforms time into a space that combines the personal and the collective memory. As Sönmez (2019) says that in the novel every object represents the atmosphere of Turkey in the 1970s even if they belong to the protagonist of the story. The protagonist's memories do not reflect a simply individual history, but rather construct the imagery of a whole nation by depicting the streets, neighborhood, houses, districts, and objects of Istanbul as seen by the protagonist. Pamuk (2012) writes as a novelist interested in the social history of his country, charging objects with a variety of associations and memories, connecting the personal to the collective. He argues that,

"We don't need more museums that try to construct the historical narratives of a society, community, team, nation, state, tribe, company, or species. We all know that the ordinary, everyday stories of individuals are richer, more humane, and much more joyful. (p. 55)

Hall (1997) points out that representation links meaning and language to culture. It means using language to represent the world meaningfully to other people or give meaning to reality. He goes on to say that representation is an essential part of the process by which meaning is produced and exchanged between members of a culture. It does involve the use of language, of signs and images, which stand for or represent things" (p. 27). Representation in Museum of Innocence is done through the objects collected by the protagonist because they represent Turkish history and culture.

Arab World English Journal for Translation \& Literary Studies 
Their value does not lie only in their significance to the lover but also in the meaning they communicate about the social history of Istanbul. The protagonist of the novel tells not only his love story but also the culture of an entire nation. The city and its context are given to us through the personal story of an individual. Pamuk, first, transforms the time and space in 20th c Istanbul into a novel and, then, into a museum based on the novel. Both the novel and the museum are records of personal things that represent the collective memory of the city.

What Pamuk's novels do is reflecting the discursive heteroglossia that resonates in Istanbul and the personal, social, cultural and political facets of lives Istanbul's dwellers' everyday experience. The image of the city presented in the two novels comes to us through the perception of the two protagonists, perceptions that were formed and influenced by Istanbul. The idea of the city in the two novels is not just limited to its geographical boundaries, rather, it is defined by the approach of the two protagonists which reflects the psychological state of the city. Thus, the identity of the city and the identity of the protagonists are, to use Vincent's words, " trapped in a vicious cycle, wherein, one impacts the other in equal measure" (Vincent, 2012, p.36). Pamuk showed us his protagonists' own identity's inseparability from Istanbul. The city setting itself becomes a type of physical system of support in which the protagonists can find concrete spaces to build their identities.

The conflict between western ideas and Othman heritage is a focal point in The Museum of Innocence. The Turkish society is presented as a traditional society with newly acquired western values. The novel depicts Istanbul, its streets, old and new neighborhoods and the best sites. Moreover, it brilliantly captured and eulogized the soul of Istanbul which is a combination of old and new values. Talking about the representation of the present and the past in urban literature Pike (1941) thinks that on the one hand, there's the obvious city of lanes and buildings. solidified shapes of vitality fixed at different times within the past and around which the active dynamic vitality of the present twirls. On the other hand, there are the intuitive streams emerging within the minds of the city's living occupants from this combination of past and present. Pamuk succeeded in giving us both" the visible city" of the present and the" the subconscious currents arising in the minds of the city's living inhabitants from this combination of past and present". Through his novels, he conveys to us his view of the past and present of Istanbul. He reveals the tension that has shaped Istanbul's development and the nostalgia for the city's history. He also showed certain reluctance to depart from the past in a drastic manner. Like the protagonists in both novels, the Istanbul depicted in the two novels grapples with being the shadow of its past and seems to have no direction for the future.

Pamuk's narrative description of Istanbul is detailed. He extensively and specifically names certain buildings and locations. For the reader, such naming refers to the history and cultural significance of the specified places. This prompts the reader to associate the character with the social, cultural, and historical significance of the location. Istanbul setting plays a very central role in psychologically and sociologically organizing the protagonists' reality and geographically locating the cultural and historical foundations of the text. The protagonist in A Strangeness in My Mind strives sub-consciously to locate a sense of identity while Kemal in The Museum of 
Innocence (2008) finds that " "Istanbul was now a galaxy of signs that reminded me of her,( Füsun)" (p. 134).

\section{Conclusion}

The role of Istanbul in Pamuk's novels moves from the setting for the action to an active element of the action. The relation between the characters in these novels and Istanbul is showcased as the relation that evolves with time, wherein, both the variables are influenced by the action of one another. The significance of the study lies in the fact that literary texts especially novels not only reveal the writer's reflections on urban space, but also show the character's experience in urban space. Therefore, the study of the representation of a city in novels offer unique way to know the city. Pamuk's novels show Istanbul as a dynamic character that changes over time. In his novels, he has characteristically investigated the tempo of social and environmental change and the image of the city is reflected in the portrayal of the individual. The physical environment of the character is a major influence on the character's experience and even subtle changes in that environment can impact one's experience. The study has shown that characterization within the two texts produces a quantified and calculated image of the city which reflects the psychological and sociological burdens of the protagonists.

\section{About the Author:}

Dr. Abdurrahman Mokbel Mahyoub Hezam is an associate professor of English literature and comparative studies at the department of English, Faculty of Arts, Taiz University. Currently he is working as Head of the department of Languages and Translation, Faculty of Science and Arts, Taibah University- Al-Ola, Saudi Arabia ID OrCid: https://orcid.org/0000-0001-9624-906X

\section{References}

Afridi, M., \& Buyze, A.(eds.). (2012). Global Perspectives on Orhan Pamuk: Existentialism and Politics, Literatures and Cultures of the Islamic World. US: Palgrave Macmillan

Brand. G. (1991). The Spectator and the City in Nineteenth-Century American Literature. New York: Cambridge University Press.

Cassirer, E. (1994). An Essay on Man. New Haven: Yale University Press

Gelfant. B. H. (1970). The American City Novel. Norman: University of Oklahoma Press

Gilmer, J. M. (2018). From Violence to Silence: Memory, History and Forgetting in Teju Cole's Open City. Teaching American Literature, 60-78.

Giustina, S. (2020). Reflections of a vanished time. The melancholy of objects in Georgi Gospodinov's and Orphan Pamuk's works. Retrieved from https://www.researchgate.net/profile/Giustina_Selvelli/publications

Hall, S. (1997) Representation: Cultural Representations and Signifying Practices. Sage Publications, London.

Harding, Desmond (2003) Writing the City: Urban Visions and Literary Modernism (Literary Criticism and Cultural Theory) Routledge.

Jaye, M., \& Chalmers, A. (eds.). (1981). Watts Literature and the Urban Experience. New Brunswick: Rutgers University Press 
Johnston, J. H. (1984). The Poet and the City. Athens: University of Georgia Press

Jones, R. E. (2014). Literature, Representation, and the Image of the Francophone City: Casablanca, Montreal, Marseille, (Unpublished Master's thesis). Los Angeles: University of California

Lefebvre, H. (1991). The Production of Space (D. Nicholson, Trans.). Massachusetts: Basil Blackwell Ltd., Cambridge.

Lehan, R (1998). The City in Literature: An Intellectual and Cultural History. Berkeley: University of California Press

Lehan, R. (1997). The City in Literature: An Intellectual and Cultural History. Berkeley: University of California Press

Levy, D. (1978). CITY SIGNS: TOWARD A DEFINITION OF URBAN LITERATURE. Modern Fiction Studies, 24(1), 65-73. Retrieved April 3, 2020, from www.jstor.org/stable/26281973Ledden, P.J. (1998). Education and Social Class in Joyce's Dublin. Journal of Modern Literature, 22(2), 329 - 336.

Lynch, K. (1960). The image of the city. Cambridge, Mass: MIT Press

Mullin, K. (2016). Cities in Modernist Literature. British Library. Retrieved 21 April from https://www.bl.uk/20th-century-literature/articles/cities-in-modernist-literature

Neumann, B., \& Kappel, Y. (2019). Music and Latency in Teju Cole's Open City: Presences of the Past. ariel: A Review of International English Literature 50(1), 31-62. doi:10.1353/ari.2019.0002.

Pike. B. (1981). The Image of the City in Modern Literature. Princeton: Princeton University Press

Rameshwar B. D. (2018). Portrayal of Mumbai in the Novels of Jeet Thayil and Kiran Nagarkar: Representation of Post-Independence India. Retrieved from www.languageinindia.com/sep2018/index.html

Sönmez, Lebriz(2019) A HETEROTOPIC AND GLOCAL PLACE: THE MUSEUM OF INNOCENCE. Trakya Üniversitesi Sosyal Bilimler Dergisi Aralı 2019 Cilt 21 Sayı 2 (1017-1029

Sryfi, M. (2018). Rethinking Space: The Representation of the City in the Moroccan Novel in Arabic Reading Muhammad Zafzaf and Muhammad Shukri, (Unpublished Doctoral dissertation). Philadelphia USA, University of Pennsylvania

Vermeulen, P. (2013). Flights of Memory: Teju Cole's Open City and the Limits of Aesthetic Cosmopolitanism. Journal of Modern Literature, 37(1), 40-57. doi:10.2979/jmodelite.37.1.40

Vincent, D. (2012). Reflections of/on the City: literature, space, and postmodernity, (Unpublished Doctoral dissertation) Leiden, Netherlands. Leiden University

Wesselman, D.V. (2012). Reflections of/on the city: literature, space, and postmodernity, (unpublished Doctoral dissertation). ICLON, Leiden, Netherlands Leiden University.

Williams, R. (1975). The Country and the City. Oxford: Oxford University Press, 